\title{
Synergistic antitumor effects of combined deguelin and cisplatin treatment in gastric cancer cells
}

\author{
ZHENGGUANG LI, CHANGPING WU, JUN WU, MEI JI, LIANGRONG SHI, \\ JINGTING JIANG, BIN XU and JINJIN YUAN
}

Department of Oncology, The Third Affiliated Hospital of Soochow University, Changzhou, Jiangsu 213003, P.R. China

Received December 31, 2013; Accepted April 24, 2014

DOI: $10.3892 / \mathrm{ol} .2014 .2368$

\begin{abstract}
Deguelin is a naturally occurring rotenoid with marked chemopreventive and antitumor activity. Cisplatin, characterized by damaging DNA, is widely used in the chemotherapy of malignancies, including gastric cancer. The present study investigated whether synergistic effects exist between the combination of deguelin and cisplatin, and the possible mechanism in vitro. The interactive effects of deguelin in combination with various concentrations of cisplatin were evaluated in the human gastric cancer MGC-803 cell line. The inhibition of cell proliferation was determined by 3-(4,5)-dimethylthiazol(-2-yl)-2,5-diphenyltetrazolium bromide assay and the mechanisms underlying the effects were further evaluated by western blot analysis. The results revealed that the combined treatment of deguelin and cisplatin exhibited a marked inhibition of MGC-803 cell proliferation when compared with that of the single therapies in vitro. In addition, isobologram analysis revealed that this combined treatment showed a synergistic effect. These observations may have promising therapeutic value for gastric cancer and thus warrant further investigation.
\end{abstract}

\section{Introduction}

Gastric cancer is the fourth and fifth most prevalent cancer diagnosed in males and females, respectively, worldwide and the third and fifth most common cause of cancer-related mortality in males and females, respectively (1). Surgical resection remains the mainstay of potentially curative treatment. However, local-regional and distant recurrences are common, and the treatment outcome is far from satisfactory (2). Thus, surgery alone is insufficient for the treatment of the majority of patients. In addition, gastric cancer is often diagnosed at an advanced stage, which is unresectable.

Correspondence to: Professor Changping Wu, Department of Oncology, The Third Affiliated Hospital of Soochow University, 185 Juqian Street, Changzhou, Jiangsu 213003, P.R. China E-mail:wcpzlk@163.com

Key words: gastric cancer, deguelin, cisplatin, synergism
Therefore, chemotherapy and chemoradiation are important for the treatment of gastric cancer, particularly in patients with advanced and metastatic disease $(3,4)$.

Platinum-based drugs have been widely used and extensively studied in anticancer therapy based on their ability to covalently bind to DNA $(5,6)$. At present, cisplatin remains the most frequently used chemotherapy for different malignances. In gastric cancer, regimens that contain platinum-based drugs have been successfully administered in perioperative and postoperative chemotherapy, as well as in chemotherapy for advanced/metastatic disease, with significant efficacy (7-10). However, despite the efficacy of platinum-based drugs against gastric cancer, concerns exist regarding the use of these agents. One concern is that cancer cells exhibit an inherent or acquired refractory to platinum, which reduces its efficacy resulting in disease relapse $(11,12)$. An additional concern is their potent toxicity and side effects, which significantly limit the tolerable therapy dose.

Deguelin is a natural rotenoid isolated from several plant species, including Mundulea sericea (Fig. 1). Deguelin has been found to exhibit marked chemopreventive and antitumor activity against cancer, in various model systems (13-15). Recently, it was reported that deguelin induces DNA damage by reducing the expression of DNA repair genes in human non-small cell lung cancer cells (16). The mechanism of platinum-refractory or platinum-resistance in vivo is multi-factorial, including increased tolerance to platinum-induced and enhanced repair of DNA damage (17-22). Thus, to investigate whether deguelin synergistically potentiates the antitumor effects of cisplatin, the interactive effects of deguelin and cisplatin in vitro were examined using the gastric carcinoma MGC-803 cell line. In addition, the synergistic effects and possible mechanisms were analyzed.

\section{Materials and methods}

Materials. 3-(4,5)-dimethylthiazol(-2-yl)-2,5-diphenyltetrazolium bromide (MTT), dimethyl sulfoxide (DMSO), propidium iodide (PI) and cisplatin were purchased from Sigma-Aldrich (St. Louis, MO, USA). The total protein extraction and comet assay kits were purchased from Nanjing Keygen Biotech., Co., Ltd. (Nanjing, China). All the chemicals used in this study were analytically pure and of culture grade. The primary antibodies against BRCA1 (monoclonal rabbit anti-human), 
ERCC1 (polyclonal rabbit anti-human), XRCC1 (polyclonal rabbit anti-human) and GAPDH (monoclonal rabbit anti-human) were purchased from Cell Signaling Technology, Inc. (Beverly, MA, USA), and the Bio-Rad protein assay kit I (cat. no. 500-0001) was purchased from Bio-Rad (Hercules, CA, USA).

Deguelin was purchased from Sigma-Aldrich, dissolved in DMSO as a stock solution and stored at $4^{\circ} \mathrm{C}$. The stock solution was then diluted in cell culture medium to a final concentration of $0.05 \%$ DMSO $(\mathrm{V} / \mathrm{V})$.

Cell culture. The human gastric cancer MGC-803 cell line was purchased from the Type Culture Collection of the Chinese Academy of Sciences (Shanghai, China). The cells were cultured in RPMI-1640 medium (Life Technologies, Bedford, MA, USA) containing $10 \%$ heat-inactivated fetal bovine serum, $100 \mathrm{U} / \mathrm{ml}$ penicillin and $100 \mathrm{U} / \mathrm{ml}$ streptomycin (all Life Technologies, Bedford, MA, USA) at $37^{\circ} \mathrm{C}$ in a humidified atmosphere with $5 \% \mathrm{CO}_{2}$.

Cell viability assay. The cell viability of the treated cancer cells was determined using the MTT assay. Briefly, cells $\left(4-5 \times 10^{3}\right)$ were seeded in 96-well plates and cultured for $24 \mathrm{~h}$, followed by deguelin and cisplatin treatment. A volume of $10 \mu \mathrm{l}$ of MTT $(10 \mathrm{mg} / \mathrm{ml})$ was added to each well and the cells were incubated for an additional $4 \mathrm{~h}$ at $37^{\circ} \mathrm{C}$. The supernatant fluid was then removed and DMSO (150 $\mu \mathrm{l} /$ well) was added for 15-20 min. The optical densities were measured at a wavelength of $570 \mathrm{~nm}$ using the SpectraMAX M5 microplate spectrophotometer (Molecular Devices, LLC, Sunnyvale, CA, USA). All experiments were performed in triplicate. The effect of deguelin on the cell proliferation was presented as the cell growth inhibition, using the following formula: Inhibition rate $(\%)=\left(\mathrm{A}_{570}\right.$ of control $-\mathrm{A}_{570}$ of treated cells $) /\left(\mathrm{A}_{570}\right.$ of control cells) x 100 .

Isobologram analysis. The interactions of the combination treatment of deguelin and cisplatin were analyzed by isobologram as previously described (23). The dose-dependent effects were determined for each compound and for one compound with fixed concentrations of the other. The combination index $(\mathrm{CI})$ was calculated according to the following formula: $\mathrm{CI}=(d 1 / D x 1)+(d 2 / D x 2)$, where $D x 1$ is the concentration of drug 1 (deguelin) required to produce $\mathrm{x}$ percentage effect alone, and $d 1$ is the concentration of drug 1 required to produce the same $\mathrm{x}$ percentage effect in combination with $d 2$. Similarly, $D x 2$ is the concentration of drug 2 (cisplatin) required to produce x percentage effect alone, and $d 2$ is the concentration of drug 2 required to produce the same x percentage effect in combination with $d 1$. The CI values were defined as follows: $<1$, synergism; 1 , additive; and $>1$, antagonism.

Morphological analysis. Following culture and drug treatment as previously described, the morphological changes of the cells were observed. The cells were fixed in $70 \%$ ethanol following washing with phosphate-buffered saline (PBS). After examination for morphological changes with an inverted microscope (XDS-800C; Ahghai Caikon Optical Instrument Co., Ltd., Shanghai, China), the cells were stained with PI $(1 \mu \mathrm{g} / \mathrm{ml}$ in

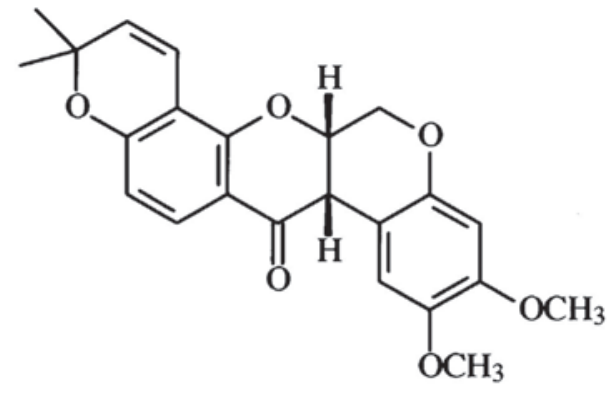

Figure 1. Chemical structure of deguelin.

PBS) and analyzed under a fluorescence microscope (Axiovert 200; Carl Zeiss, Göttingen, Germany).

Western blot analysis. Following treatment with deguelin and cisplatin, $5 \times 10^{6}$ cells were harvested and lysed in $1 \mathrm{ml}$ lysis buffer (Nanjing Keygen Biotech., Co., Ltd.), and the protein concentration was determined using the Bio-Rad protein assay reagent (Bio-Rad). The samples were then denatured in sample buffer and the proteins were separated by sodium dodecyl sulfate-polyacrylamide gel electrophoresis. Next, the gels were electroblotted onto a polyvinylidene difluoride membrane, rinsed with Tris-buffered saline with Tween 20 [20 mM Tris, $500 \mathrm{mM}$ $\mathrm{NaCl}$ and $0.1 \%$ Tween-20 (pH 7.6)] and blocked with 5\% non-fat milk in blocking buffer. The membrane was incubated with the appropriate primary antibody overnight at $4^{\circ} \mathrm{C}$. The membrane was then incubated with the appropriate peroxidase-conjugated secondary antibody and the immunoreactive bands were visualized using the enhanced chemiluminescence method.

Statistical analysis. Data are presented as the mean \pm standard deviation and statistical analyses were performed using the analysis of variance test. All data were analyzed using SPSS version 13.0 (SPSS, Chicago, IL, USA) and $\mathrm{P}<0.05$ was considered to indicate a statistically significant difference.

\section{Results}

Effects of deguelin and cisplatin on cell proliferation. The antiproliferative effects of deguelin and cisplatin alone on MGC-803 cells were investigated using the MTT assay. Deguelin and cisplatin treatment resulted in a dose- and time-dependent decrease in cell viability. Furthermore, when cells were treated with deguelin for 48 and $72 \mathrm{~h}$, the $\mathrm{IC}_{50}$ values were 10.74 and $6.52 \mu \mathrm{g} / \mathrm{ml}$, respectively. The $\mathrm{IC}_{50}$ values of cells treated with cisplatin for 24,48 and $72 \mathrm{~h}$ were $22.90,7.66$ and $3.89 \mu \mathrm{g} / \mathrm{ml}$, respectively (Fig. 2).

Combined effects of deguelin and cisplatin. The effects of cisplatin combined with deguelin in a series of concentrations were examined. When combined with deguelin, the $\mathrm{IC}_{50}$ of cisplatin in MGC-803 cells was found to decrease significantly, in a dose-dependent manner. For example, when the concentration of deguelin increased from 1.56 to $6.25 \mu \mathrm{g} / \mathrm{ml}$, the $\mathrm{IC}_{50}$ of cisplatin was found to decrease from 4.69 to $1.45 \mu \mathrm{g} / \mathrm{ml}$ (Fig. 3).

To evaluate the interaction between deguelin and cisplatin, isobologram analysis was performed and the 

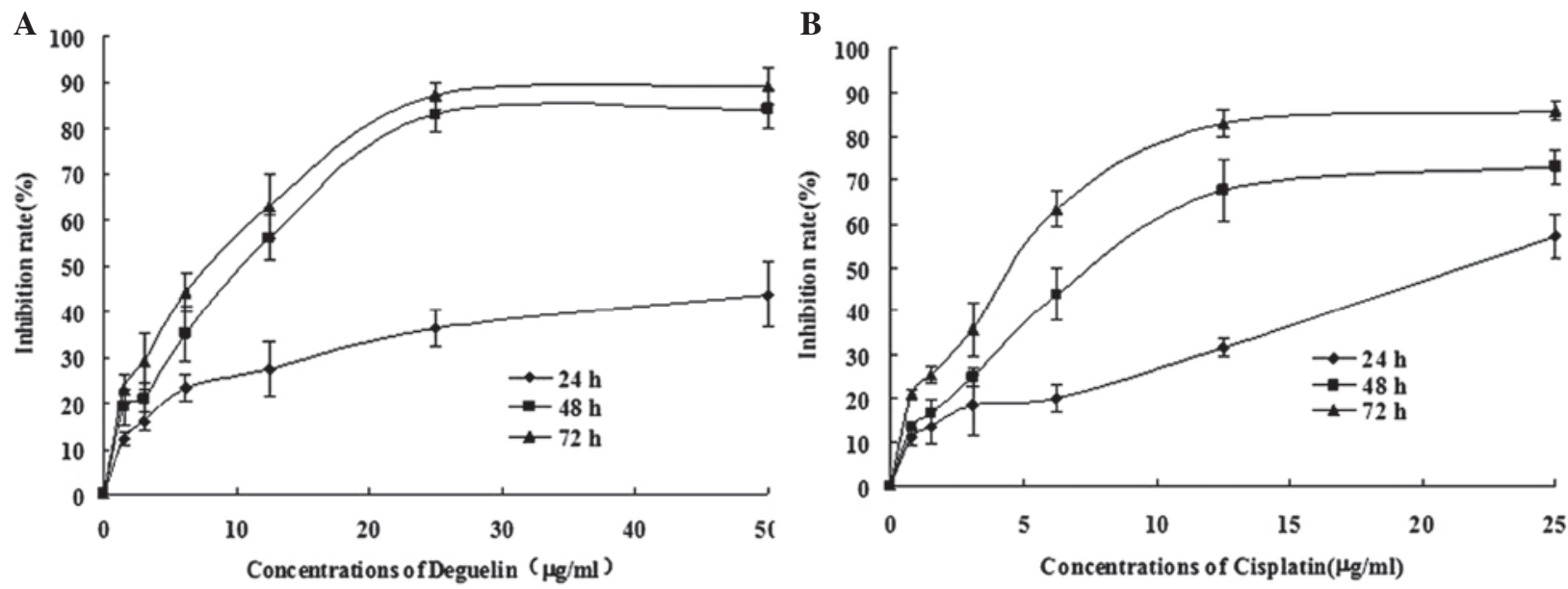

Figure 2. Inhibition of the proliferation of MGC-803 cells treated with (A) deguelin or (B) cisplatin. Cell viability experiments were performed following 24, 48 and $72 \mathrm{~h}$ of exposure to the compounds. Each point and vertical bar presents the mean \pm standard deviation of three independent experiments.

A

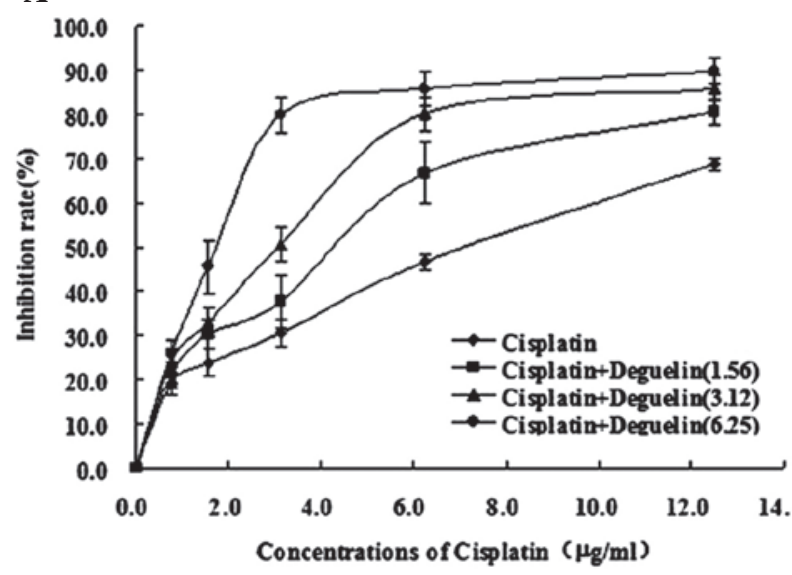

B

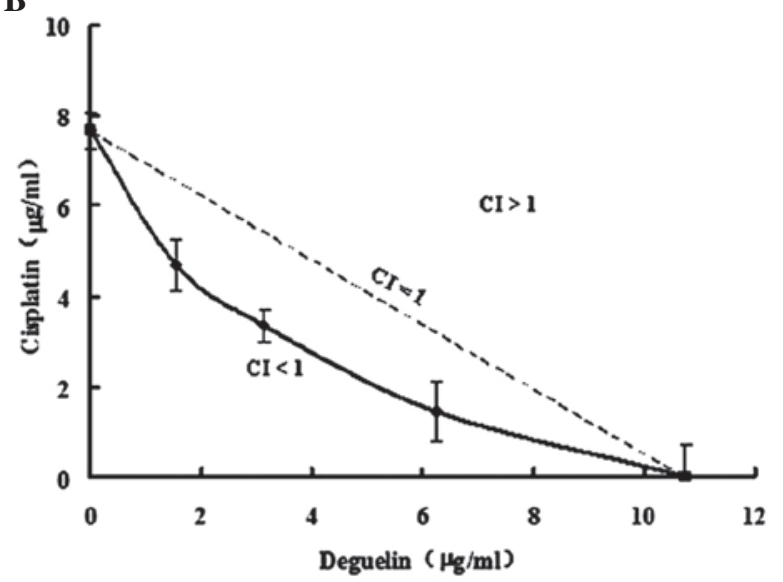

Figure 3. (A) Combined effects of deguelin and cisplatin and (B) isobologram analysis. MGC-803 cells were treated with cisplatin combined with deguelin at various concentrations $(0,1.56,3.12$ and $6.25 \mu \mathrm{g} / \mathrm{ml})$. According to the data, when deguelin $(1.56,3.12 \mathrm{and} 6.25 \mu \mathrm{g} / \mathrm{ml}) \mathrm{was}$ combined with cisplatin $(4.49$, 3.34 and $1.45 \mu \mathrm{g} / \mathrm{ml}$, respectively), the CI was $<1(0.72,0.75$ and 0.76 , respectively). Each point and vertical bar presents the mean \pm standard deviation of three independent experiments. CI, combination index.

results showed that the CI was considerably $<1$ when deguelin and cisplatin were used in combination; $\mathrm{CI}=0.72$ for $1.56 \mu \mathrm{g} / \mathrm{mg}$ deguelin combined with $4.49 \mu \mathrm{g} / \mathrm{mg}$ cisplatin; $\mathrm{CI}=0.75$ for $3.12 \mu \mathrm{g} / \mathrm{mgdeguelincombined} \mathrm{with} 3.34 \mu \mathrm{g} / \mathrm{mgcispl}-$ atin; and $\mathrm{CI}=0.76$ for $6.25 \mu \mathrm{g} / \mathrm{mg}$ deguelin combined with $1.45 \mu \mathrm{g} / \mathrm{mg}$ cisplatin). These results indicated that deguelin and cisplatin exhibit synergistic effects which inhibit the growth of MGC-803 cells (Fig. 3).

Furthermore, fluorescence microscopic examination of PI-stained cells was performed to confirm the synergistic effects between deguelin and cisplatin. Following treatment with $3 \mu \mathrm{g} / \mathrm{ml}$ cisplatin and $6.25 \mu \mathrm{g} / \mathrm{ml}$ deguelin, the cell number was significantly lower than that of the groups treated with cisplatin or deguelin alone. However, the number of apoptotic cells had increased (Fig. 4).

Mechanistic studies of deguelin-cisplatin synergism. To identify the molecular mechanisms underlying the synergism between deguelin and cisplatin, the expression of various DNA damage repair genes was examined. The results revealed that BRCA1 expression was significantly decreased following the treatment of MGC-803 cells with deguelin alone or deguelin-cisplatin in combination for $48 \mathrm{~h}$, while no significant differences were identified in the expression of ERCC1 and XRCC1. However, treatment with cisplatin alone was not observed to alter the expression of BRCA1, ERCC1 or XRCC1 (Fig. 5).

\section{Discussion}

Gastric cancer is prevalent in a number of countries worldwide, accounting for $7.8 \%$ of all novel cancer cases and $\sim 800,000$ mortalities per year $(1,24)$. Despite the progress in recent years, the treatment outcome of gastric cancer remains unsatisfactory with a five-year survival rate of $<30 \%$. Therefore, novel drugs are urgently required to improve the treatment of this malignancy.

Cisplatin, a representative platinum-based drug, is one of the most commonly used drugs in the therapy of malignancies, 
A

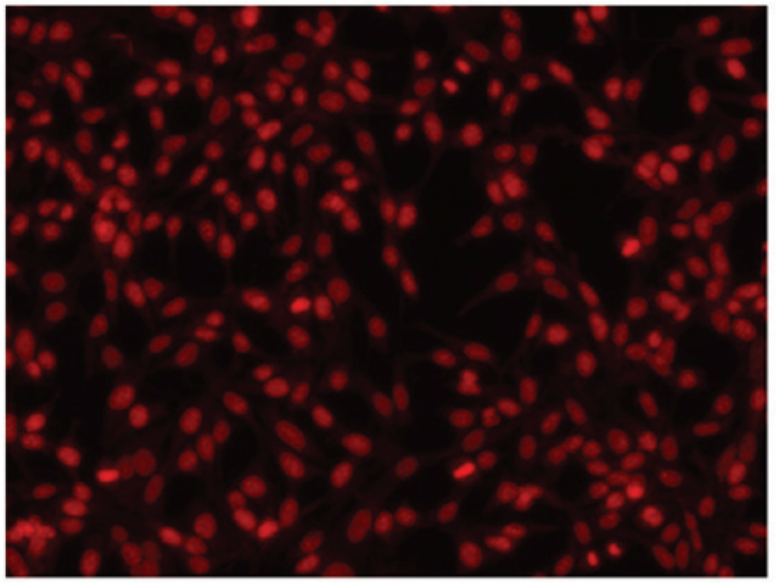

C

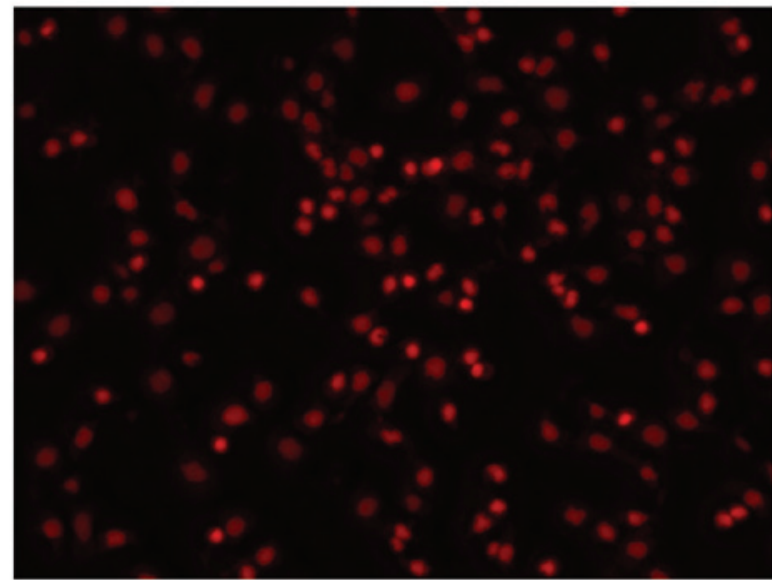

B

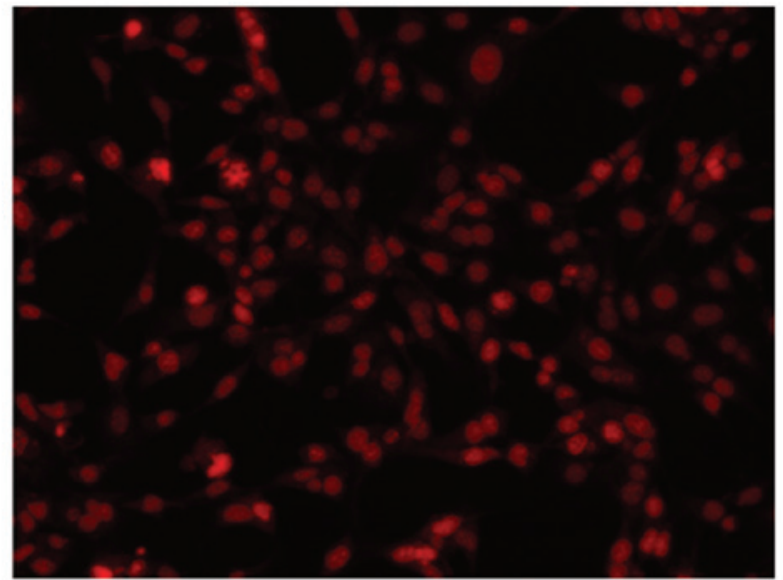

D

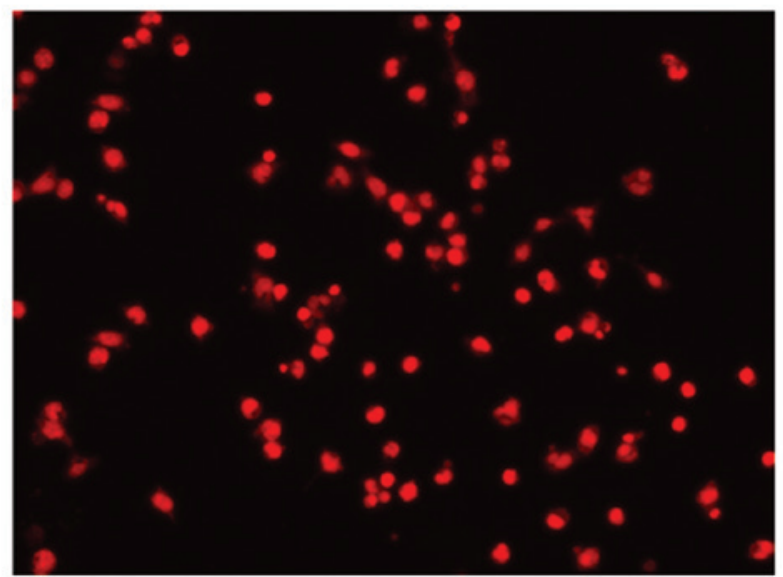

Figure 4. Morphological changes induced by deguelin and cisplatin. Fluorescence microscopy of propidium iodide-stained nuclei of the (A) untreated control group and MGC-803 cells treated with (B) $6.25 \mu \mathrm{g} / \mathrm{ml}$ deguelin, (C) $3 \mu \mathrm{g} / \mathrm{ml}$ cisplatin or (D) a combination of deguelin $(6.25 \mu \mathrm{g} / \mathrm{mg}) \mathrm{and}$ cisplatin (3 $\mu \mathrm{g} / \mathrm{mg}$ ) for $48 \mathrm{~h}$ (magnification, $\mathrm{x}$ 400). Apoptotic cells containing condensed and fragmented fluorescent nuclei were visible in the barbigerone-treated cells, but not in the untreated cells.

A

\section{B}

BRCA1

ERCC1

XRCC1

\section{GAPDH}

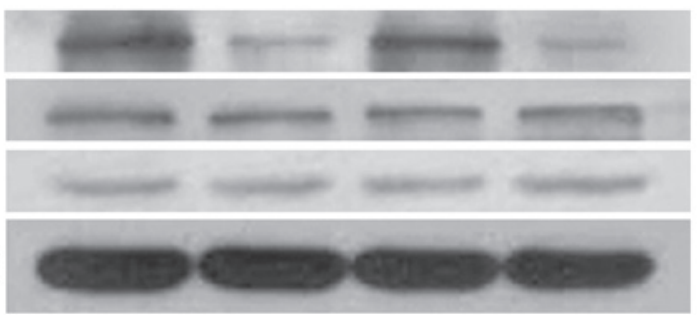

Figure 5. Effect of deguelin on the DNA damage repair genes. MGC-803 cells were treated with $6.25 \mu \mathrm{g} / \mathrm{ml}$ deguelin, $3 \mu \mathrm{g} / \mathrm{ml}$ cisplatin or the two drugs in combination $(6.25 \mu \mathrm{g} / \mathrm{mg}$ deguelin and $3 \mu \mathrm{g} / \mathrm{mg}$ cisplatin) for $48 \mathrm{~h}$ and the expression levels of BRCA1, ERCC1 and XRCC1 were analyzed by western blot analysis. GAPDH was used as a loading control. BRCA1 was downregulated following exposure to deguelin, but ERCC1 and XRCC1 were not affected.

such as gastric cancer $(25,26)$. In cancer cells, platinum-based drugs efficiently bind to DNA to form a variety of covalent adducts, which block replication and transcription and eventually induce cell apoptosis or necrosis (27). As DNA damage exerts antitumor effects, increasing DNA repair may decrease the sensitivity of cells or induce resistance to platinum-based drugs $(28,29)$. However, if DNA repair is inhibited, the platinum-based drugs may exhibit more efficient antitumor effects.

Deguelin, a naturally occurring rotenoid, is capable of inhibiting phosphatidylinositide 3-kinase in premalignant and malignant human bronchial epithelial cells (13). It has been reported that deguelin markedly enhances the sensitivity of human U937 leukemia cells and acute myeloid leukemia blasts to chemotherapeutic drugs via the downregulation of Akt phosphorylation (30). However, the influences of deguelin on platinum based drugs remain unclear. Therefore, in the present study, the interaction between deguelin and cisplatin was examined in the gastric cancer MGC-803 cell line.

In the present study, deguelin was found to inhibit the proliferation of gastric cancer cells in a time- and dose-dependent manner. Furthermore, DNA damage in cells was induced by deguelin via the downregulation of DNA repair genes, consistent with a previous report (16). When combined with deguelin, the antitumor effect of cisplatin was enhanced. Furthermore, the combination of deguelin with cisplatin was found to increase the therapeutic efficacy of each drug, resulting in a synergistic interaction $(\mathrm{CI}<1)$. In addition, these results indicated that the inhibition of DNA damage repair via the downregulation of BRCA1 underlies the synergistic effect of deguelin and cisplatin. 
In conclusion, deguelin in combination with cisplatin exhibits a synergistic and significant antitumor effect in gastric cancer cells. This may have promising therapeutic value for gastric cancer and thus warrants further investigation.

\section{Acknowledgements}

This study was supported by the Technology Project of Changzhou Social Development (grant no. CS20102016).

\section{References}

1. Jemal A, Bray F, Center MM, Ferlay J, Ward E and Forman D: Global cancer statistics. CA Cancer J Clin 61: 69-90, 2011.

2. Songun I, Putter H,Kranenbarg EM, Sasako M and van de Velde CJ: Surgical treatment of gastric cancer: 15-year follow-up results of the randomised nationwide Dutch D1D2 trial. Lancet Oncol 11: 439-449, 2010.

3. Jain VK, Cunningham D and Chau I: Preoperative and postoperative chemotherapy for gastric cancer. Surg Oncol Clin N Am 21: 99-112, 2012.

4. Pasini F, Fraccon AP and DE Manzoni G: The role of chemotherapy in metastatic gastric cancer. Anticancer Res 31: 3543-3554, 2011.

5. Lebwohl D and Canetta R: Clinical development of platinum complexes in cancer therapy: an historical perspective and an update. Eur J Cancer 34: 1522-1534, 1998.

6. Monneret C: Platinum anticancer drugs. From serendipity to rational design. Ann Pharm Fr 69: 286-295, 2011.

7. Kang YK, Kang WK, Shin DB, et al: Capecitabine/cisplatin versus 5-fluorouracil/cisplatin as first-line therapy in patients with advanced gastric cancer: a randomised phase III noninferiority trial. Ann Oncol 20: 666-673, 2009.

8. Koizumi W, Tanabe S, Saigenji K, et al: Phase I/II study of S-1 combined with cisplatin in patients with advanced gastric cancer. Br J Cancer 89: 2207-2212, 2003.

9. Van Cutsem E, Moiseyenko VM, Tjulandin S, et al; V325 Study Group: Phase III study of docetaxel and cisplatin plus fluorouracil compared with cisplatin and fluorouracil as first-line therapy for advanced gastric cancer: a report of the V325 Study Group. J Clin Oncol 24: 4991-4997, 2006.

10. Cunningham D, Allum WH, Stenning SP, et al: Perioperative chemotherapy versus surgery alone for resectable gastroesophageal cancer. N Engl J Med 355: 11-20, 2006.

11. Rennicke A, Voigt W, Mueller T, et al: Resistance mechanisms following cisplatin and oxaliplatin treatment of the human teratocarcinoma cell line 2102EP. Anticancer Res 25: 1147-1155, 2005

12. Timmer-Bosscha H, Mulder NH and de Vries EG: Modulation of cis-diamminedichloroplatinum(II) resistance: a review. Br J Cancer 66: 227-238, 1992.

13. Chun KH, Kosmeder JW II, Sun S, et al: Effects of deguelin on the phosphatidylinositol 3-kinase/Akt pathway and apoptosis in premalignant human bronchial epithelial cells. J Natl Cancer Inst 95: 291-302, 2003.
14. Lee HY, Oh SH, Woo JK, et al: Chemopreventive effects of deguelin, a novel Akt inhibitor, on tobacco-induced lung tumorigenesis. J Natl Cancer Inst 97: 1695-1699, 2005.

15. Murillo G, Salti GI, Kosmeder JW II, Pezzuto JM and Mehta RG: Deguelin inhibits the growth of colon cancer cells through the induction of apoptosis and cell cycle arrest. Eur J Cancer 38: 2446-2454, 2002.

16. Ji BC, Yu CC, Yang ST, et al: Induction of DNA damage by deguelin is mediated through reducing DNA repair genes in human non-small cell lung cancer NCI-H460 cells. Oncol Rep 27: 959-964, 2012.

17. Altaha R, Liang X, Yu JJ and Reed E: Excision repair cross complementing-group 1: gene expression and platinum resistance. Int J Mol Med 14: 959-970, 2004.

18. Choi MK and Kim DD: Platinum transporters and drug resistance. Arch Pharm Res 29: 1067-1073, 2006.

19. Howell SB, Safaei R, Larson CA and Sailor MJ: Copper transporters and the cellular pharmacology of the platinum-containing cancer drugs. Mol Pharmacol 77: 887-894, 2010.

20. Olaussen KA, Mountzios G and Soria JC: ERCC1 as a risk stratifier in platinum-based chemotherapy for nonsmall-cell lung cancer. Curr Opin Pulm Med 13: 284-289, 2007.

21. Saldivar JS, Wu X, Follen M and Gershenson D: Nucleotide excision repair pathway review I: implications in ovarian cancer and platinum sensitivity. Gynecol Oncol 107 (Suppl 1): S56-S71, 2007.

22. Wernyj RP and Morin PJ: Molecular mechanisms of platinum resistance: still searching for the Achilles' heel. Drug Resist Updat 7: 227-232, 2004.

23. Hou W, Chen L, Yang G, et al: Synergistic antitumor effects of liposomal honokiol combined with adriamycin in breast cancer models. Phytother Res 22: 1125-1132, 2008.

24. Choi KS, Jun JK, Park EC, et al: Performance of different gastric cancer screening methods in Korea: a population-based study. PLoS One 7: e50041, 2012.

25. Hainsworth JD, Johnson DH and Greco FA: Cisplatin-based combination chemotherapy in the treatment of poorly differentiated carcinoma and poorly differentiated adenocarcinoma of unknown primary site: results of a 12-year experience. J Clin Oncol 10: 912-922, 1992.

26. Ohtsu A, Shimada Y, Yoshida S, et al: Phase II study of protracted infusional 5-fluorouracil combined with cisplatinum for advanced gastric cancer: report from the Japan Clinical Oncology Group (JCOG). Eur J Cancer 30A: 2091-2093, 1994.

27. Fuertes MA, Castilla J, Alonso C and Pérez JM: Cisplatin biochemical mechanism of action: from cytotoxicity to induction of cell death through interconnections between apoptotic and necrotic pathways. Curr Med Chem 10: 257-266, 2003.

28. Brabec V: DNA modifications by antitumor platinum and ruthenium compounds: their recognition and repair. Prog Nucleic Acid Res Mol Biol 71: 1-68, 2002.

29. Brabec V and Kasparkova J: Modifications of DNA by platinum complexes. Relation to resistance of tumors to platinum antitumor drugs. Drug Resist Updat 8: 131-146, 2005.

30. Bortul R, Tazzari PL, Billi AM, et al: Deguelin, a PI3K/AKT inhibitor, enhances chemosensitivity of leukaemia cells with an active PI3K/AKT pathway. Br J Haematol 129: 677-686, 2005. 